Practical Control of Wireworm with 'Gammexane'

From the beginning of the War a considerable programme of work on the control of wireworm by chemical means was prosecuted by these laboratories. Following the discovery of the insecticidal properties of the gamma isomer of 1.2.3.4.5.6-hexachlorocyclohexane ('Gam-
mexane') in 19421, it seemed likely that the new agent might control wireworm attack.

After laboratory and small-plot work had established dosage rates that would not damage cereal crops, two small field trials were laid down in the autumn of 1943 and spring of 1944. Of these, the latter was most encouraging; the treated strips showed improved stands in relation to those of the controls, and the wireworm populations were definitely reduced. The autumn trial showed little wireworm attack in any strip.

The small fleld trials were sufficiently promising to warrant extended trials in 1944-45, and accordingly sixteen trials, all on winter wheat, were laid down in the autumn of 1944 and thirty-one trials, mainly on oats, in the spring of 1945 . Very considerable help in selecting the sites was given by the war agricultural executive committee and the provincial advisory entomologists, particularly those of and the provincial advisory entomologists, particularly those of wireworm populations, ranging from half to one and a half million larvø (more than $5 \mathrm{~mm}$. in length) per acre. Most of the flelds were lirst year after grass.

Without exception, wherever the new insecticide was used, the treated strips showed excellent stands. As expected, in the case of treated strips showed excellent stands. As expected, in the case of with increase in observed wireworm population. Some of the unwith increase in observed wireworm population. Some

The chemical was applied in various ways, from which two may be The chemical was applied in various ways, from which two may be
selected on the grounds of immediate practical interest : (1) Prepara-
tion broadcast as a dust and harrowed in just before or after sowing tion broadcast as a dust and harrowed in just before or after sowing.
(2) Preparation in the form of a dust combine-drilled with the seed (2) Preparation in the form of a dust combine-drilled with the seed. In both cases the content of the gamma isomer in the dust was about 1-6 cwt. per acre in the various trials.

In general, it was found that a 65 per cent reduction in wireworm population followed the broadcast application of dust at the rate of $3 \mathrm{cwt}$ /acre (that is, $0.84 \mathrm{lb}$. of 'Gammexane' per acre), while as much as 50 per cent reduction followed the combine drilling of dust at the rate of $1 \mathrm{cwt}$./acre (that is, $0.28 \mathrm{lb}$. of 'Gammexane' per acre).

The bulk of the trials were on cereals, as already mentioned, but three trials with Brassicæ showed equally promising results.

It is hoped to publish a full account of these trials elsewhere when all crop yield figures are available. Further trlals are in hand to amplify the work; but it is already clear, on the evidence available that preparations based on this new insecticide provide, for the first time, practical and economic means for the control of attack by wireworm.

Imperial Chemical Industries, Ltd., F. J. D. Thomas.

Jealott's 'Hille Laboratories, Bracknell, Berks.

1 Slade, R. E., Chem. and Ind., 40, 314 (1945).

\section{Cobalt as a Preventive of 'Pining' in Cornwall and Devon}

UNTIL recently, all evidence of the use of cobalt as a preventive or cure of 'pining' in sheep has been conflned to Scotland ${ }^{1,3}$ and the north of England ${ }^{3}$, although attention was directed in $1937^{4}$ and 1938 to 'pining' and its possible connexion with low cobalt content of soil and pastures in Devon. During the past eighteen months, furthe study has shown that the condition is fairly widespread on soils derived from granite and Old Red Sandstone grits in both Devon and Cornwall.

In some parts of Cornwall, it is customary for farmers on the granite areas to own or rent a 'change' farm on soils derived from Middle Devonian shales to which the stock are sent for overwintering as a preventive of 'pining'. Analysis of the soils and pastures from such a pair of farms gave the accompanying results :

COBAIT IN PARTS PER MILLION.

\begin{tabular}{|c|c|c|c|c|}
\hline & \multicolumn{2}{|r|}{ Soils } & \multicolumn{2}{|c|}{ Pasture } \\
\hline & Mean & Range & Mean & Rango \\
\hline $\begin{array}{l}\text { 'Pining' Farm } \\
\text { 'Change' Farm }\end{array}$ & $\begin{array}{l}0.033 \\
1.211\end{array}$ & $\begin{array}{r}\text { nil }-0.060 \\
0.575-2 \cdot 105\end{array}$ & $\begin{array}{l}0.05 \\
0.14\end{array}$ & $\begin{array}{l}0.01-0 \cdot 07 \\
0.11-0.16\end{array}$ \\
\hline
\end{tabular}

In soils, this refers to cobalt soluble in 2.5 per cent acetic acid ; in pastures, to total cobalt. These figures are not comparable with those given in refs. 4 and 5 , which referred to 'total cobalt', but are comparable with those given in refs. 1 and 2 and by Mitchell (ref. 6 ). In experiments carried out at the above 'pining' farm in Cornwall on the effect of cobalt administered as a drench giving $1 \mathrm{mgm}$. cobalt a day on preventing 'pining', the average live-weight increase of members of the control group over a period of three months (April 25August 1) was $8.9 \mathrm{lb}$, and of those receiving cobalt was $37.6 \mathrm{lb}$. giving a difference of '28.7 $\mathrm{lb}$, in favour of those receiving cobalt. The most striking fact was that during the last month of the trial, eighteen of the twenty control animals died while showing all the usual symptoms of 'pining', while all but one of the treated sheep remained healthy. This constitutes the first authenticated instance of cobalt as a preventive of 'pining' in Cornwall.

On Dartmoor, in a similar trial in which both groups of animals were dosed with phenothiazine, animals in the control group gained an average of $0.3 \mathrm{lb}$. over a period of six weeks, while those receiving cobalt in addition to phenothiazine gained a statistically signiffcant average of $8 \cdot 2 \mathrm{lb}$. a head. Further work has been and will be done, and will be published more fully elsewhere.

The Laboratory,

J. B. E. Patrerson.

Dartington Hall Trustees,

Totnes, Devon.

Jan. 29.

${ }^{1}$ Stewart, J., Mitchell, R. L., and Stewart, A. B., Emp. J. Exp. Agric., 9, 145 (1941)

stewart, J., Mitchell, R. L., and Stewart, A. B., Emp. J. Exp. Agric., 10, 57 (1942)

Corner, H. H., and Smith, A. M., Biochem. J., 32, 1800 (1938).

- Patterson, J. B. F., Nature, 140, 363 (1937).

- Matterson, J. B. E., Emp. J. Exp. Agric., 6, 262 (1938).

A Climatic Index IT is generally recognized that one of the most satisfactory single-
value climatic indices in estimating the efficiency of rainfall for the purposes of agriculture and plant ecology is the Transeau ratio of precipitation to evaporation from a free water surface ${ }^{1}$, or the Meyer ratio of precipitation to atmospheric saturation deficit?.

It has been increasingly obvious to those making frequent use of these indices that a constant ratio rarely holds over a wide range of climate extending from the temperate regions to the tropics. The ratios appropriate to tropical conditions are generally lower than ratios appropriate to tropical conditions are

$A$ recent examination of a variety of data has made it possible to suggest a new index, namely, the ratio of precipitation to some power of evaporation. That is, for constant edaphic conditions so ar as soil moisture relationships are concerned

$$
\frac{P}{E^{m}}=I \text {. }
$$

Two examples may be given. The index has been found to hold for the climatic boundaries separating the four major soil zones of Australia as delineated in my map of $1944^{8}$, when both rainfall and
evaporation are taken as mean annual values.

\begin{tabular}{|c|c|c|}
\hline Soil boundaries & $m$ & $I$ \\
\hline $\begin{array}{c}\text { Between desert formations and grey } \\
\text { and brown soils }\end{array}$ & $0 \cdot 70$ & $0 \cdot 47$ \\
$\begin{array}{c}\text { Between grey and brown soils and } \\
\text { black and red-brown soils } \\
\text { Between black and red-brown solls } \\
\text { and podsols }\end{array}$ & $0 \cdot 70$ & 0.92 \\
\hline
\end{tabular}

The second example is derived from the mean monthly records of the Rothamsted drain gauges as discussed by Crowther'. An equation with signiflcant regression coefficients has the form

$$
D=3.81 \log P-1.81 \log E-0.05,
$$

where $D$ is the drainage, $P$ the rainfall and $E$ the evaporation from a free water surface as estimated from the saturation deficit. The regression can be expressed in the form

$$
\log \frac{P}{E^{0.47}}=\frac{D+0.05}{3.84}
$$

When drainage is nil, the value of the index is 1.03

Waite Agricultural Research Institute,

J. A. PREscott. Adelaide. Jan. 21

1 Transeau, E. N., Amer. Nat., 39, 875 (1905).

Mejer, A., Chem. d. Erde, 209 (1926)

Prescott, J. A., Aust. Coun. Sci. Ind. Res. Bull., 177 (1944).

Crowther, E. M., Proc. Roy. Soc., B, 107, 1 (1930).

Establishment of Beneficial Insects in Trinidad, B.W.I.

TRINIDAD is a continental island and, in contrast with oceanic islands like Fiji, Hawaii and Mauritius, affords an unfavourable biological environment for the establishment of introduced insect parasites and predators. The only beneflcial species, apart from the honeybee, which have become successfully established appear to be the thrips parasite, Dasyscapus parvipennis Gahan, and the Javanese beetle, Ploesius javanus Erichson.

Dasyscapus parvipennis is a minute parasitic wasp which attacks various species of thrips, including the cacao thrips, Selenothrips rubrocinctus (Giard), an important pest of cacao in the West Indies, West Africa and Brazil. This parasite was introduced into Trinidad from the Gold Coast in 1935 by Adamson ${ }^{1}$, who gives an account of breeding in the laboratory and liberation in the fleld. Although it has been successfully established in Trinidad, no economic control of the cacao thrips has unfortunately resulted

Plosius javanus is a beetle which is predaceous on the banana weevil borer, Cosmopolites sordidus Germar, an important pest in almost all banana-growing countries. Originally found in Java, this predator was introduced many years ago into Fij1, where it became established. Subsequent introductions into numerous other countries have been made, but so far as I am aware it has only been established in Fiji, Queensland, Tahiti, Jamaica and Trinidad. The introduction into Queensland was made from Java several years ago, whilo that into Tahiti was made from Fiji in 1937 and appears to while that onspicuously successfulbo. The in 1937 and appears to have been by introductions from Fiji in 1937, 1938 and $1939^{3,4}$, and that in 